Soc. Geogr. Discuss., 4, 1-25, 2008

www.soc-geogr-discuss.net/4/1/2008/

(C) Author(s) 2008. This work is distributed under

the Creative Commons Attribution 3.0 License.

Social

\title{
Making a difference: tourist practices of repeat visitors in the city of Paris
}

\section{T. Freytag}

Department of Geography, University of Heidelberg, Heidelberg, Germany

Received: 21 February 2008 - Accepted: 25 February 2008 - Published: 17 March 2008

Correspondence to: T. Freytag (tim.freytag@geog.uni-heidelberg.de)

Published by Copernicus Publications.

Tourist practices of repeat visitors in

Paris

T. Freytag

Title Page

Abstract Introduction

Conclusions

References

Tables

Figures

14

4

$>$

Back

Full Screen / Esc

Printer-friendly Version

Interactive Discussion

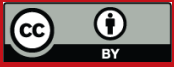




\section{Abstract}

In the context of sustained growth in European city tourism, competing travel destinations develop marketing strategies that include measures to attract an increasing number of repeat visitors. This paper explores the case of Paris in order to provide a better 5 understanding of the specific motivations, interests and activities of leisure tourists who had previously stayed in the capital of France. Drawing on Pierre Bourdieu's concept of "distinction" it is argued that repeat visitors tend to differentiate themselves from other tourists. On the basis of substantive field work in Paris, a set of repeat visitor practices is presented that include strategies to avoid spatial concentrations of major 10 tourist spots in order to participate in Parisian everyday life. Moreover, it is suggested to conceptualize the encounters between repeat visitors and tourism destinations as a lifelong relationship, which can be renewed and reproduced through further visits and virtual encounters. The distinct characteristics of repeat visitor practices have substantial implications for the organization of tourism in the city and the relationships between 15 first-time tourists, repeat visitors and the local population.

\section{Introduction}

European city tourism has increased considerably over the past decade. Urban tourist destinations are particularly attractive for travelers who do not follow the traditional mode of concentrating their annual travel activities in a long summer holiday in a sea or mountain resort, but prefer several short vacations per year (Becker, 2000). With the exception of small children and their families, more and more visitors of all ages feel particularly attracted by urban and metropolitan places. This has lead to considerable changes in the structure and use of central cities (Knafou, 2007). The actual growth in city tourism is also fuelled by transport companies (especially low-cost airlines) and travel agents who offer inexpensive trips and packages (Groß and Schröder, 2007). In addition, many cities have started to make significant investments in tourism marketing

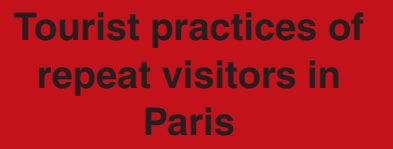

\section{Title Page}

Abstract Introduction

Conclusions References

Tables Figures

14

4

$\checkmark$

Back Close

Full Screen / Esc

Printer-friendly Version

Interactive Discussion 
as they observe the growing potential of tourism as major resource in the expanding service economy (Freyer, 2005).

In the context of an increasing competition between travel destinations, city tourism promoters are turning their attention to repeat visitors as a separate target group (Jag5 now and Wachowiak, 2000). In Paris, a new tourism marketing strategy is being applied to increase the number of repeat visitors. The aim is to stage more events and to promote a new image of a young and trendy city, which is less centred on monuments and museums. The key slogans of the new strategy are: cosmopolitan Paris, creative Paris, and friendly Paris (expert interview E; translated by author). However, the 10 particular motivation, interests and activities of repeat visitors still constitute a largely unexplored field in city tourism marketing and academic research (Kozak, 2001; Wang, 2004). Notwithstanding a growing interest in the consumption side of urban tourism, many questions remain unanswered (Shaw et al., 2000; Selby, 2004). Can we identify specific practices of repeat visitors that are distinct from the practices of other types 15 of tourists? If so, why do repeat visitors choose specific practices? And what are the implications for the visitors, the tourism promoters and the people living in the city?

The aim of this paper is to provide a better understanding of tourist practices with a focus on repeat visitors who stay in a city for leisure purposes. Drawing on the concept of "distinction", developed by the French sociologist Pierre Bourdieu (1979),

20 it is argued that repeat visitors tend to differentiate themselves from first time visitors and mass tourism. Based on several months of field work in Paris, it is suggested that repeat visitors do not correspond to the traditional role of a tourist (as portrayed, for example, in Hennig, 1999).

The paper is divided into three main sections. The first part gives a brief account 25 of relevant definitions, followed by explanatory remarks on methodology, conceptual framework and field work for data collection. The second part provides a portrait of Paris as one of the leading city tourism destinations in the world. It will be discussed how the spatial organization of tourism has changed over time and what the currently most important tourist attractions and visitor activities are. At the heart of this paper is

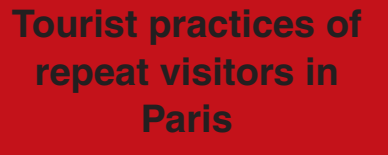

Title Page

Abstract Introduction

Conclusions References

Tables Figures

$1<$

- I

4

$\checkmark$

Back

Close

Full Screen / Esc

Printer-friendly Version

Interactive Discussion

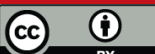


an empirically informed analysis of leisure tourist practices, which will be presented in the third part. The concluding section considers the implications of the findings for the future organization of city tourism.

\section{Definitions, methodology and conceptual framework}

\subsection{Tourism, repeat visitors and tourist practices}

The phenomenon of tourism implies mobility and circulation (Urry, 2000; Williams and Hall, 2002). According to the World Tourism Organization (UNWTO), tourism can be defined as a "set of activities engaged in by persons temporarily away from their usual environment, for a period of not more than one year, and for a broad range of leisure, business, religious, health, and personal reasons, excluding the pursuit of remuneration from within the place visited or long-term change of residence" (cit. in Smith, 2004:29). Due to the additional UNWTO criterion that the visitors should spend at least one night away from their home, the term tourism is usually not applied to day-trips.

According to the wide range of possible travel purposes, several types of tourists can

be distinguished. Moreover, the frequency of visits can be used to define tourist categories. The term "repeat visitor" describes experienced tourists, who - in opposition to first time visitors - already made a previous visit to one and the same destination. However, the boundaries between these categories are blurred. We can observe hybrid forms of visitors when, for example, a business tourist uses part of the available time budget for leisure purposes. Even the boundary between first time and repeat visitors is not absolutely clear. As this paper will show, tourists who stay in Paris for a second or third time still have much in common with first time visitors. Only if they stay more frequently or for longer periods of time in the city, visitors tend to show practices that can be regarded as typical for experienced repeat visitors. Basically, this is a result of the great variety of tourist attractions in Paris, which cannot all be visited during one stay. Consequently, repeat visitors are defined in this paper as experienced tourists

Tourist practices of repeat visitors in Paris

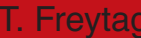

Title Page

Abstract Introduction

Conclusions References

Tables $\quad$ Figures

14

$\Delta \mathbf{I}$

4

$\triangleright$

Back Close

Full Screen / Esc

Printer-friendly Version

Interactive Discussion

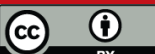


who have come to Paris at least three times before their present visit. The distinction between first time and repeat visitors has to be understood as a heuristic framework of two distinct types of tourists that are located at the two ends of a continuum.

Focusing on the consumption side of tourism it can be helpful to analyze social, cul5 tural and economic practices (Urry, 1990; Crouch, 2004). Compared to behavioural approaches that understand tourist behaviour as a result of a given structural and environmental context (Pearce, 1982, 1988), the consideration of tourist practices attributes more autonomy to the individual and the social context (Giddens, 1984). Tourist practices can be defined as a set of learned competences and skills (including specific 10 norms and expectations) articulated in routine activities and refering to temporary encounters that tourists have with their environment (Sacareau and Stock, 2003:21-32). Moreover, tourist practices have the potential to change over time and to vary between different types of travellers (Équipe MIT 2002, 2005).

\subsection{From Bourdieu's concept of "distinction" to tourist practices of differentiation}

15 The extensive work of Pierre Bourdieu is centered on the idea that social and cultural practices (re)produce difference in the formation and preservation of class categories. This phenomenon was observed by Bourdieu and Passeron (1970) in the context of educational institutions before it became a key element of a wider social analysis which can be read as a theory of taste and life style. In "La distinction" (Bourdieu, 1979)

20 the French sociologist suggests to consider practices as socially constructed and situated ways of living. Bourdieu argues that practices are mainly motivated by the aim to identify with a specific social class and to differentiate between one's own and the others' social class categories. His empirical research shows that practice is a structured process that can be observed in the manifold activities of everyday life. Practices are understood and conceptualized as a way of classifying individuals due to their relative positions within a social space, which is structured by accumulating social, cultural and economic capital. Accordingly, even small differences in social and cultural practices can mean important distinctions in terms of social class belonging.

\section{SGD}

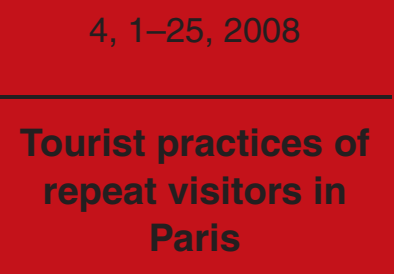

Title Page

Abstract Introduction

Conclusions References

Tables $\quad$ Figures

$1<$

DI

4

$\checkmark$

Back

Close

Full Screen / Esc

Printer-friendly Version

Interactive Discussion

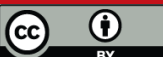


In the field of tourism consumption Bourdieu's theoretical approach has been used to explain how class distinctions are produced and reproduced through specific tourist practices (Britton, 1991). For example, historically aristocrats moved from Brighton to the French Riviera when the construction of railroad lines made the British sea resorts 5 accessible for the middle and working classes (Buzard, 1993; Towner, 1996). As they did not wish to share these travel destinations with lower social classes, aristocrats changed their travelling habits and successfully preserved their exclusive tourism environment. In a similar way, middle class tourists reveal practices to accumulate cultural capital and to distance themselves from the working class whose tourist practices are 10 generally considered as purely leisure-oriented, focused on the beach, and ignorant of local cultures (Hennig, 1999). According to this view, middle class travellers often aim to experience authentic food and culture, whereas working class tourists prefer not to change their habits of consumption during the holidays. As, for example, MacCannell (1976:9-10) points out, the term tourist is frequently used pejoratively with disdain and 15 rejection.

In this paper Bourdieu's approach of "distinction" will be transferred from class categories to different types of visitors in urban tourism. Based on experiences with the Heidelberg visitor survey (Freytag, 2002), it is doubted that visitor behaviour and visitor practices show as uniform patterns as suggested by Keul and Küheberger (1996), who compare tourist mobility with ant trails. At least beyond the beaten tracks of tourism, we can observe some degree of variation. But, along which lines do visitor behaviour and visitor practices appear to be structured? What are the relevant parameters: Is it a matter of weather conditions, length of stay, origin of the visitors, social class, age, gender or educational attainment? This paper will argue that the distinction between first time and repeat visitors is crucial for an understanding of visitor practices in urban tourism.

SGD
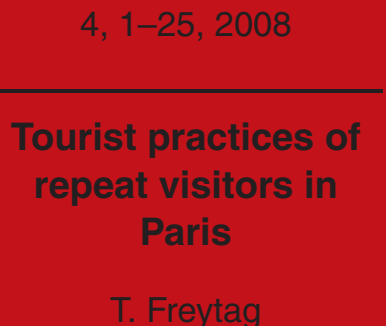

Title Page

Abstract Introduction

Conclusions References

Tables Figures

1

4

$>$

Back

Full Screen / Esc

Printer-friendly Version

Interactive Discussion 


\subsection{Paris field work}

The article is based on extensive field work conducted between September 2006 and February 2007 in the city of Paris. This included a visitor survey, a series of expert interviews and participant observation. The aim of the data collection was to provide 5 the empirical basis for explorative research on leisure tourist practices.

The visitor survey consists of 201 questionnaire based interviews that were carried out with tourists from 35 countries from all over the world in the following languages: English (80 participants), German (47), French (34), Spanish (24), Italian (13) and Russian (3). The participants of the sample were randomly approached in various places

10 in Paris (Louvre court, Pompidou centre, Montmartre, metro etc.). In less touristy areas it proved to be difficult and time-consuming to identify visitors that were willing to take part in the survey. For this reason, the analysis was complemented by expert interviews and observation techniques. The main topics of the questionnaire included information about the purpose and duration of the stay, a detailed account of activities, 15 questions of environmental perception, and socio-demographic characteristics of the visitors.

Moreover, ten in-depth expert interviews were carried out with decision makers from the local tourist board, the city council and several tour operators and other professionals in tourism services. The interview conversations of approximately 30 to $45 \mathrm{~min}$ were digitally recorded, documented as transcripts and analysed with MAXqda software. The interviews included questions about the actual situation and future perspectives for Paris as a tourist destination, strategies and activities of specific tourism associations and organisations, and new trends in tourism marketing. Due to the confidential character of the conversations, all interview quotations are anonymized in this paper.

During six months in Paris the author had the opportunity to observe tourism and visitor practices in a variety of more or less touristy places including numerous museums and exhibitions, shopping and eating places, public parks and cemeteries, and the Parisian metro and bus transport system. Participant observation was practiced in a

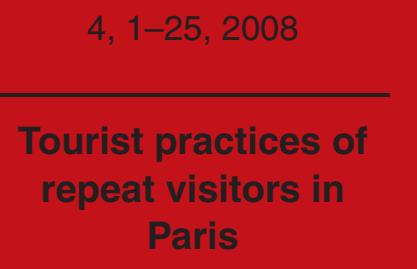


selection of guided city tours that were offered by the following associations: Office $d u$ Tourisme de Paris, Ça se visite!, Paris Go, and Club International des Jeunes à Paris.

The findings from the field work are framed by a critical reading and analysis of more than 30 contemporary and historical travel guides in English, French, and German. 5 The selected material includes rather traditional guides (several editions published by Baedeker, Dumont, Merian, and Michelin etc.), but also city guides aimed at a young and trendy audience (for example, Fodor's, Guide du Routard, Let's Go, Lonely Planet and Rough Guide), and further travel information that is accessible via the website of the local tourist board.

\section{Paris - the European capital of city tourism}

As a travel destination Paris evokes multi-faceted and particularly capturing imageries that are portrayed in countless travel guides: The iconic landmark of the Eiffel Tower and the controversial glass pyramid of the Louvre, impressive Haussmannian boulevards that dress the city in cream-grey limestone, numerous cafés and restaurants, the

15 Montmartre hill with tiny lanes and squares filled with street painters, the glamorous Champs-Elysées boulevard that stretches from the obelisk of place de la Concorde to Arc de Triomphe, magnificent views of the river Seine from Pont-Neuf, and the famous cathedral of Notre-Dame (see for example, Bohlmann-Modersohn, 2007; Office du Tourisme et des Congrès de Paris, 2006:14-17). The city of Paris is widely associated with impressing architecture, arts and culture, lifestyle, fashion, shopping, delightful food, pleasure and romance. Being the capital and by far the most important city of France, Paris symbolically represents the country as a whole, and - at least from an international perspective - the images of Paris and France, which have been constructed over many centuries, are closely interrelated (Pletsch, 2000).

Historically, Paris was an important part of the Grand Tour that flourished between the late 17th and early 19th century, when young upper-class men used to travel across Europe for more or less educational purposes (Towner, 1996). However, most of the

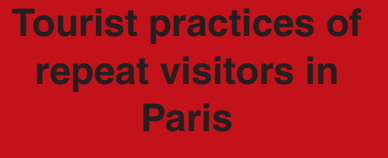

Title Page

Abstract Introduction

Conclusions References

Tables Figures

14 - I

4

$\checkmark$

Back Close

Full Screen / Esc

Printer-friendly Version

Interactive Discussion

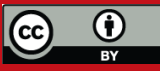


imaginary of Paris as a tourist destination goes back to the 19th century, when the modern city of Paris took shape (Sheringham, 1996). The process of urban transformation and modernization was closely related with a rapidly growing number of visitors due to the rise in railroad travel since the mid 19th century (Vajda, 2007). The increas5 ing importance of tourism is reflected in contemporary travel guide literature (Hancock, 2003) and also in the expansion of the 19th century world's fair exhibitions $(1855,1867$, 1878,1889 and 1900), which were held in Paris with successively rising numbers of visitors and an ever increasing exhibition area. During the second half of the 19th century, the number of visitors of Paris world's fairs grew considerably from 5 million (1855) 10 to more than 50 million (1900) as reported by Aimone and Olmo (cit. in Duhamel and Knafou, 2007:47). The architectural remains of the world's fairs, all of which are located in the western part of the city between place de la Concorde and Champs de Mars, include several emblematic monuments, such as the Eiffel Tower, Pont Alexandre III, and Grand and Petit Palais.

According to key tourism indicators, Paris can be identified as the European capital of tourism and one of the most important urban tourism destinations in the world (Freytag, 2007). As expert interviewee B puts it, "Paris successfully attracts all kinds of leisure and business travellers because the city and its imagery are very well known as a tourist destination, which has most impressive cultural and architectural resources. 20 Moreover, Paris is perfectly integrated in national and international transport systems" (translated by author). In 2005, the French capital counted roughly 1500 hotels that accommodated more than 15 million visitors who spent a total of 33.7 million bednights (Insee; cit. in Observatoire économique du tourisme parisien, 2006). Taking into account the greater Île-de-France region, the mentioned tourism figures must be doubled. With a ratio of almost 60 per cent of the overnight visitors to Paris, the city is an important destination for international tourists. The leading resident countries of international travellers are the US and UK, followed by Italy, Japan, Spain, and Germany. As a result of its function as political and economic centre of France, Paris attracts a large number of business travellers that are estimated to be more than 44 per cent of

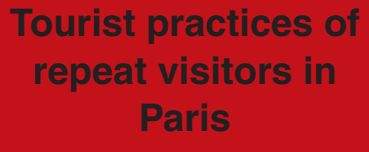

Title Page

Abstract Introduction

Conclusions References

Tables Figures

14 DI

4 $\checkmark$

Back Close

Full Screen / Esc

Printer-friendly Version

Interactive Discussion

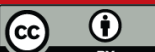


the overnight visitors. The importance of business travel is also reflected in a large number of congress and exhibition facilities, both within the city and in the surrounding Île-de-France region. During the past decade, Paris followed the general trend of urban tourism in Europe and experienced a considerable annual growth rate of approximately 53 per cent (Freytag, 2007).

Due to its relatively small surface area of only 105 square kilometres, Paris as a whole is characterised by an extreme density of both resident population and tourists who live and stay within the city limits. On a smaller scale, however, it is possible to observe distinct tourist districts within the city that show specific structural and func10 tional characteristics (Pearce, 1998a, b). The term "Central Tourist District (CTD)" is suggested by Duhamel and Knafou (2007:49) to designate urban areas that are "primarily spaces of confirmed tourist practices, which combine sight-seeing spots, areas to stroll around, shopping and eating places, and partly residential use" (translated by author). According to this approach the course of the Seine can be regarded as the 15 main structural axis of the spatial organization of tourism in Paris. Moreover, Duhamel and Knafou (2007) identify two established core areas within the Parisian CTD (see Fig. 1): First, the historical centre of pre-modern Paris (stretching from Île de la Cité to both riversides), and second, western Paris with grand boulevards and major monuments (that were shaped during the 19th century by Haussmannian architecture and the world fairs' building activities).

Conceptually, the CTD can be understood as a space that is produced and constantly reproduced through the practices of visitors, tourism professionals and decision makers in the city. Considering their spatial dimension it can be observed that visitor practices are mainly structured by the major tourist sights. This is supported by Fagnoni and

25 Aymard (2002) who argue that the major monuments and the architectural and cultural heritage of the city form the basis for tourism in Paris. According to the number of visitors in 2005, the most important tourist locations are the cathedral of Notre-Dame (13 million visitors) and the church of Sacre-Coeur $(8 \mathrm{~m})$, which are both free of charge (Observatoire économique du tourisme parisien, 2007). Among the most important

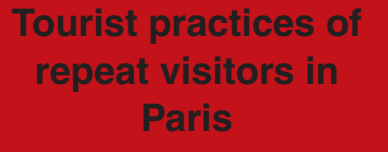

Title Page

Abstract Introduction

Conclusions References

Tables Figures

14 - I

4 $\checkmark$

Back Close

Full Screen / Esc

Printer-friendly Version

Interactive Discussion

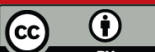


tourist sights with admission fee are the Musée du Louvre $(7.6 \mathrm{~m})$, Eiffel Tower $(6.4 \mathrm{~m})$, Pompidou centre $(5.3 \mathrm{~m})$, Cité des Sciences et de l'Industrie $(3.2 \mathrm{~m})$, Musée d'Orsay $(2.9 \mathrm{~m})$, and Arc de Triomphe $(1.3 \mathrm{~m}){ }^{1}$ In the surrounding Île-de-France region the most important tourist attraction is Disneyland Resort Paris (12.3 million visitors in 5 2005), followed by the castles of Versailles and Fontainebleau, and the cathedral of Chartres.

The Paris visitor survey reveals that tourists usually have a clear list of priorities what to do and where to go during their stay (see Table 1). This is particularly evident for first time visitors, but it also applies to tourists who come for the second or third time to

10 Paris. Aside from the mentioned monuments, the visitor survey identifies the ChampsÉlysées and the grand boulevards as major tourist activity spaces. The general pattern of visitor practices during the stay widely corresponds with the activities that are recommended by travel guides for spending a few days in Paris (see for example, Klurman, 2004:18-21; Brabis, 2006:52-56).

\section{Tourist practices that make a difference}

Even before arriving for the first time in Paris, a tourist necessarily has an idea about the city and its major sights (Urry, 1990). As the mini Rough Guide to Paris puts it, no "visitor sees Paris for the first time - images of the city are endlessly reproduced on calendars and postcards around the world, and it has been the setting for count20 less films and novels" (Blackmore and McConnachie, 2006:4). This type of common knowledge about Paris consists of stereotypical images, which (in the case of $28.0 \%$ of the first time visitors in the survey) were complemented by personal travel reports and recommendations of people who previously visited the city. Moreover, a tourist may

\footnotetext{
${ }^{1}$ The indicated numbers of visitors are based on sold tickets. Consequently, they are not strictly limited to tourists, but include visiting residents and day-trippers. However, the indicated volume of visitors documents the relative importance of the listed sights and monuments as tourist attractions.
}

SGD

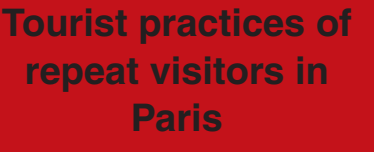

Title Page

Abstract Introduction

Conclusions References

Tables $\quad$ Figures

1

$>$ I

4

$\checkmark$

Back

Close

Full Screen / Esc

Printer-friendly Version

Interactive Discussion

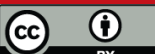


draw information from the internet $(51.2 \%)$ or travel guides $(39.0 \%)$ in order to prepare the trip and develop more or less specific plans and expectations for the stay. Only few of the interviewed first time visitors asked the hotel reception $(6.1 \%)$ or the local tourist office $(3.7 \%)$ for tourism related information. The stereotypical character of the basic 5 knowledge about a tourist place like Paris can be regarded as a major reason why first time visitors appear to be magically attracted by the most important sightseeing spots and monuments (see Table 1). Due to the great number of visitor attractions a similar pattern of visiting practices is shown by tourists who come for the second or third time to Paris and still feel the need to complete the standard visitor programme. However, 10 the expert interviews and observation practices suggest that more experienced repeat visitors often neglect or even avoid the iconic places of mass tourism.

\subsection{Moving beyond mass tourism circuits}

During their first stay in Paris, most tourists are very active in moving and getting around in the city. They walk over long distances $(68.3 \%$ of the interviewed first time visitors, $65.4 \%$ of the second or third time visitors, and $49.2 \%$ of the more experienced repeat visitors) and frequently use the metro transport system $(84.1 \%, 84.6 \%$, and $79.4 \%)$ in order to get to the major tourist attractions. First time visitors feel the need to physically visit the places, which they already know from pictures and stories. A successful holiday break can be achieved by following a densely packed visitor programme which low more than superficial encounters with the places to be visited. First time visitors often rush from one place to another and may get stressed if they do not manage to get through the whole programme. ${ }^{2}$ As Crang (2004:81) points out, a key element of tourism is not going to places or being at places, but rather attaining the status of

\footnotetext{
${ }^{2}$ This is also reflected in the time, when the tourists get up in the morning. $68.3 \%$ of the interviewed first time visitors get up before 9 o'clock, $46.8 \%$ of the second or third time visitors, and only $40.7 \%$ of the more experienced visitors.
}
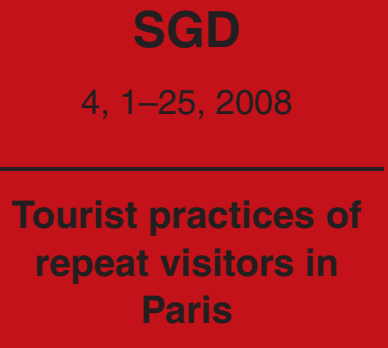

Title Page 
"having been to" somewhere. Consequently, it is possible to predict the urban mobility patterns of first time visitors. A strong concentration of tourist mobility paths was confirmed in tracking studies that were carried out in the cities of Salzburg, Regensburg and Acre (Keul and Küheberger, 1996; Bödeker, 2003; Shoval and Isaacson, 5 2007:291-295). Away from these beaten tracks, first time visitors may feel lost and out of place, with little of interest for them to discover.

In general, repeat visitors organize their stay in a different way, which gives more emphasis to individual features depending on personal interests, needs and attitudes. We can assume that repeat visitors usually are able to find their way through the city 10 and are roughly informed about the major tourist sights, most of which they already know from earlier visits. The main aim of repeat visits is to enjoy the atmosphere and environment of the city. Having accomplished the "musts" of a first time visit, repeat visitors can sporadically return to the major tourist sights, but first of all start to search for what they judge as authenticity beyond mass tourism. In order to have more spontaneous encounters and to appreciate some hidden details off the tourist tracks, repeat visitors adopt a slower and more relaxed visitors' rhythm. Whereas first time visitors only get some quick impressions of the major tourist sights, repeat visitors aim at constructing a more integrated and less tourism oriented picture of the complexity of the city.

Trying to understand why repeat visitors develop such characteristic aspirations, we can observe that they judge themselves as being somewhat superior to first time visitors. Many repeat visitors are convinced that they have a better and less superficial perception, and that they can value more adequately the places they are visiting. This attitude towards first time visitors is justified by repeat tourists through reference to their 25 accumulated knowledge and experience from previous visits, and is an integral part of their identity as repeat visitor. This identity is formed through practices which mark an opposition to first time visitors. Taking pictures, rushing from one tourist attraction to another and similar tourist practices, which are generally attributed to first time visitors, are often rejected by repeat visitors. A common feature of more experienced travellers

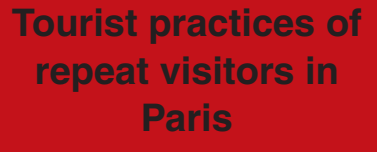

Title Page

Abstract Introduction

Conclusions References

Tables Figures

14 DI

4

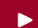

Back Close

Full Screen / Esc

Printer-friendly Version

Interactive Discussion

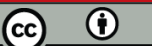


is to distance themselves from the newcomers - not only through practices, but also spatially. Repeat visitors tend to avoid some of the major tourist sights, or - if they do visit those sights - find excuses, such as coming at the best time of the day or other explanations that distinguish and value them compared to mass tourists. This obser5 vation is supported by Table 1 that shows that first time visitors feel more frequently being surrounded by too many tourists than repeat visitors do.

Interestingly, first time visitors tend to save some of the Parisian tourist attractions for another visit. This applies primarily to major museums that require a certain amount of time and attention by the visitors, such as the Musée d'Orsay. Moreover, the Marais 10 can be identified as an area which is particularly appreciated by repeat visitors. Being asked what they were planning to do differently on the occasion of their next stay in Paris, first time visitors stated that they want to stay longer in order to take more time visiting the city and its museums and also do more shopping. Visitors who already stayed once or twice in Paris confirmed that they intend to pay more attention to less 15 touristy places during their next visit and some of them are keen to study French in order to spend more time with the residents. Experienced repeat visitors stated in the survey that they like to spend time in museums and exhibitions in order to explore them more profoundly, and they are primarily interested in parts of the city that are less touristy and allow them to experience Parisian everyday life.

\subsection{Trying to take part in the everyday life of the local population}

In the process of "distinction" between first time visitors and themselves, the local population is an important reference point for repeat visitors. The local population is considered to be authentic, which is an equivalent of everyday life beyond mass tourism. For this reason, repeat visitors search for proximity with the local population, feel at25 tracted by residential quarters and other places that are part of Parisian everyday life. As expert interviewee $\mathrm{G}$ explains, this is "primarily the case in the eastern parts of the city, such as Belleville and the Canal St. Martin area, for example. Experienced visitors like to observe the non-touristy aspects of the city, they feel being in the right place if

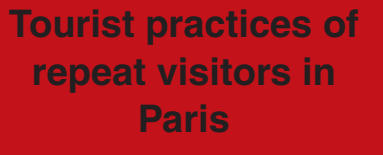

Title Page

Abstract Introduction

Conclusions

References

Tables

Figures

14

$>1$

4

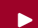

Back

Close

Full Screen / Esc

Printer-friendly Version

Interactive Discussion

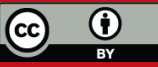


there is no apparent tourist around" (translated by author). In order to immerse themselves in "Parisian life", repeat visitors often aim to take on habits of the residents and look for opportunities to get in touch with the local population and eventually practice French language (Sallet-Lavorel, 2003). Establishing a privileged relationship with the 5 local population is regarded as the most valuable form of spending time in the city.

Using the French term "habiter" Lazzarotti $(2006,2007)$ and Stock (2007) point out, that tourists can be considered as individuals who temporarily inhabit an urban place. As many residents also often live temporarily in the city, it is questionable to take tourists and residents as strictly separate categories. Even if repeat visitors remain 10 tourists rather than "true" residents for the local population, it can be agreed that hybrid forms exist. This applies, for example, to the case of international exchange students or professionals who live in the city for several months or maybe even more than one year. In a similar way repeat visitors can be regarded as hybrids characterized by distinct visitor practices that neither correspond with mass tourism nor with residency.

Tourism professionals have already discovered that repeat visitors are interested in encounters with the local population. The Office de Tourisme de Paris and other tourism organizations started to launch specific programs, such as Paris with Parisians and other types of participatory tourism. ${ }^{3}$ Similar activities can be observed in other metropolitan cities, such as Harlem, New York, and Berlin-Kreuzberg (Huning and Novy, 2006). However, this kind of alternative tourism depends on volunteers and needs to be supported by public funds, as it seems to be impossible to operate such activities profitably on a commercial basis (expert interviews $\mathrm{C}$ and $\mathrm{K}$ ).

\footnotetext{
${ }^{3}$ The relevant organizations (including Ça se visite!, Paris Go, and Club International des Jeunes à Paris) offer a variety of guided thematic tours and visits to neighbourhoods off the beaten tourism tracks.
}

SGD
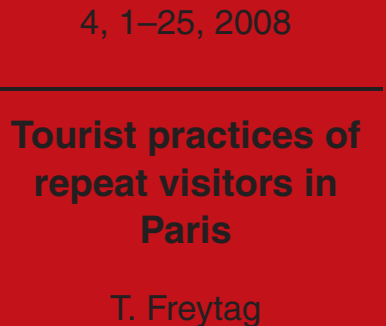

Title Page

Abstract Introduction

Conclusions References

Tables Figures

14

4

$\checkmark$

Back

Full Screen / Esc

Printer-friendly Version

Interactive Discussion 


\subsection{Establishing a long term relationship with urban tourist destinations}

The opportunity to escape temporarily from one's usual life and work environment and to be able to explore unknown places can be regarded as a major motivation for leisure tourism. Tourist places and services are consumed because they provide pleasurable 5 experiences that are different from those encountered in everyday life. Distance means relief and can be a source of inspiration. However, in the case of repeat visitors the mobility is directed to a place which is rather well-known. Regardless of the noisy and lively character of an urban environment, the setting is often perceived as a good place to relax and to let one's mind wander without being disturbed by the troubles 10 and obligations of everyday life at home. In fact, repeat visits can be seen as several steps in a process of spatial and environmental appropriation. Arriving with some basic stereotypical knowledge, first time visitors experience a tourist destination during their first stay. They accumulate knowledge and expertise, which can be completed on the occasion of repeat visits and also (without physical presence) through the media,

15 film, photographs, literature and travel guides, for example. Conceptually, the ongoing accumulation of cultural capital can be seen as a lifelong activity. A series of visits - either for leisure or business purposes - forms the basis for constructing a lifelong relationship with specific (more or less touristy) places. This can be enforced by longterm stays, for example, when studying or working abroad for a while or finding a living place for retirement (Williams and Hall, 2000).

Understanding the visitor's relationship with a city as a lifelong project enables us to consider the role of mobile information and communication technologies as hybrid interfaces between virtual and material worlds of travel. Introducing the term "blended geographies", Molz (2006) argues that travellers tend to integrate modern communication technologies before, during and after their travel activities. Tourists consult internet pages for preparing a trip, they can use interactive services during their stay, and they document their tourist experience in travel-blogs on the internet. Location based services have a great potential for tourism marketing (Meng et al., 2004) and it can be as-

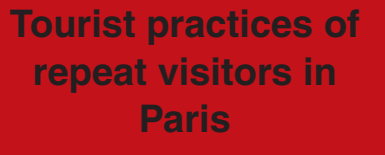

Title Page

Abstract

Introduction

Conclusions

References

Tables

Figures

14

$\rightarrow 1$

4

$>$

Back

Close

Full Screen / Esc

Printer-friendly Version

Interactive Discussion

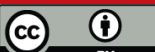


sumed that they will contribute to substantial changes in visitor practices. In the case of Paris, for example, the local tourist board and ZeVisit suggest audio and video guided virtual tours that are available on the internet (see http://en.parisinfo.com/5945-zevisit-, access: 7 February 2008).

5 Another interactive amalgam between virtual and material worlds can be observed in the case of famous movies and novels that are set in Paris and happen to be used to enhance tourism. For example, tourists can explore Montmartre on the tracks of the "Fabulous destiny of Amélie Poulain" (directed by Jean-Pierre Jeunet in 2001) or follow the path of the two main characters in Dan Brown's "The Da Vinci Code" (2003; film 10 adaptation in 2006 by Ron Howard) and explore the French capital from this novelistic angle.

\section{Conclusions}

Leisure tourist practices are learned and routinized encounters between the visitor and a travel destination. Consequently, visitor activities and expectations should not simply 15 be regarded as a result of the local setting (such as length of stay, weather conditions, locally available tourist attractions etc.) and socio-demographic characteristics of the travellers. In fact, what to do and where to go when being a visitor in a tourist place, appears to be first of all socially constructed, shared through travel reports and recommendations, and constantly reproduced through tourist practices, which can change 20 over time and vary according to the cultural background of the visitors (Jules-Rosette, 1994).

In the case of repeat visitors, it can be observed that tourist practices reflect and reproduce part of the traveller's identity. Repeat visitor practices do not only consist of "more advanced" encounters between the tourist and a place, but they underline visitors. However, both types of tourists, first time and repeat visitors, should not be seen as closed categories, but rather as the two extremes of a continuum, along which

\section{SGD}
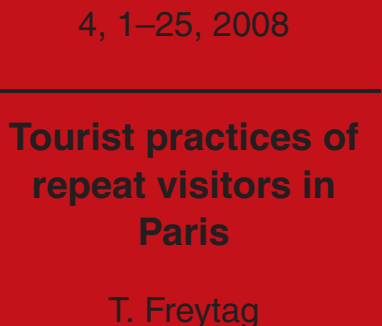

Title Page

Abstract Introduction

Conclusions References

Tables $\quad$ Figures

14

4

$\checkmark$

Back

Close

Full Screen / Esc

Printer-friendly Version

Interactive Discussion

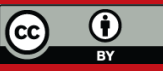


we can empirically observe numerous hybrid forms of tourists.

From a supply side perspective repeat visitors are perceived as an increasingly important target group in urban tourism. Repeat visitors are particularly keen on engaging more profoundly with selected cultural attractions, exploring less touristy parts of 5 the city and getting in touch with the residents and their everyday life activities. However, there are still considerable difficulties to appeal to customers with the existing programmes of participatory tourism because many repeat visitors tend to ignore organized tourism activities. This may change in the future, as we can expect a growing number of repeat visitors due to a general increase of leisure and business travel mo10 bility and intensified marketing activities to promote cities as competing tourism destinations. Also, we can assume that future repeat visitors will integrate more of the suggested participatory activities into their tourist practices.

Modern information and communication technologies (including location based services) will soon become more important for getting around in an urban destination and 15 organizing a tourist stay in real time. At present, these technologies are developed and tested for mass tourism, and it is only a matter of time until they will be more widely used and also implemented for participatory tourism in less touristy areas. Mobile phones with GPS technology can be used for spatial orientation, and it is possible to develop tours or games that allow to explore neighbourhoods interactively guided by one's mobile phone. Moreover, it is possible to display current information about smaller cultural events and activities that are organized on a city district level for residents and interested tourists. The modes of virtual and blended travel can also serve as incentives to intensify a lifelong relationship with a travel destination and thus augment the likeliness of repeat visits. As soon as it will be possible to operate participatory tourism on an economically profitable basis, we will see a process of professionalization, expansion and growing competition in this segment. In the long run, travellers will get more and more used to applying these technologies both in tourism and in their everyday life. Repeat visitors might even be able to transfer part of their proficiency from one city to another. All this will have a profound impact on tourist practices and on the organiza-

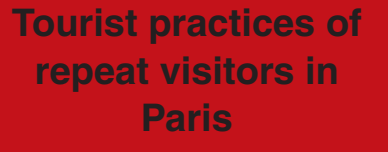

Title Page

Abstract Introduction

Conclusions

References

Tables

Figures

14

- I

4

$\checkmark$

Back

Close

Full Screen / Esc

Printer-friendly Version

Interactive Discussion

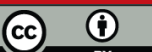


tion of tourism destinations. It will be a challenge to deal with carrying capacities and to balance the spatial organization of tourism according to the needs and interests of first time visitors, repeat visitors and the residents in the city.

Acknowledgements. My research was generously supported by the Maison des Sciences de

5 l'Homme and the Deutscher Akademischer Austauschdienst. These two institutions allocated a study grant for six month of field work and research activities on city tourism in Paris. I am most grateful to R. Knafou (Université de Paris 1 - Sorbonne; IREST) and his working group Mobilités, Itinéraires, Tourismes (équipe MIT) for their kind hospitality and many inspiring meetings and fruitful discussions. Moreover, I would like to thank all participants in the interviews 10 and my Heidelberg students E. Dietrich and H.-J. Weber for their support in carrying out the visitor survey. Finally, I owe special thanks to $\mathrm{M}$. Hoyler and $\mathrm{H}$. Jöns for thoughtful comments and linguistic advice on an earlier version of this paper.

\section{References}

Becker, C.: Freizeit und Tourismus in Deutschland: Eine Einführung, in: Nationalatlas Bundesrepublik Deutschland: Freizeit und Tourismus, edited by: Institut für Länderkunde, Spektrum Akademischer Verlag, Heidelberg, 12-21, 2000.

Blackmore, R. and McConnachie, J.: The mini Rough Guide to Paris, Rough Guides, New York, 2006.

Bödeker, B.: Städtetourismus in Regensburg: Images, Motive und Verhaltensweisen von Altstadttouristen, Ph.D. thesis, Fakultät für Biologie, Chemie und Geowissenschaften, Universität Bayreuth, available at: http://opus.ub.uni-bayreuth.de/volltexte/2003/37/index.html, access: 7 February 2008, 2003.

Bohlmann-Modersohn, M.: Paris: Merian live!, Travel House Media, München, 2007.

Bourdieu, P.: La distinction, Éditions de Minuit, Paris, 1979.

25 Bourdieu, P. and Passeron, J.-C.: La reproduction: Eléments pour une théorie du système d'enseignement, Éditions de Minuit, Paris, 1970.

Brabis, D. (Ed.): Paris: Le guide vert, Michelin, Paris, 2006.

Britton, S.: Tourism, capital, and place: Towards a critical geography of tourism, Environ. Plann. D, 9, 4, 451-478, 1991.

\section{Tourist practices of \\ repeat visitors in \\ Paris

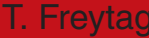

Title Page

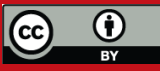


Buzard, J.: The beaten track: European tourism, literature, and the ways to 'culture', 18001918, Clarendon Press, Oxford, 1993.

Crang, M.: Cultural geographies of tourism, in: A companion to tourism, edited by: Lew, A. A., Hall, C. M. and Williams, A. M., Blackwell, Oxford, 74-84, 2004.

5 Crouch, D.: Tourist practices and performances, in: A companion to tourism, edited by: Lew, A. A., Hall, C. M. and Williams, A. M., Blackwell, Oxford, 85-95, 2004.

Duhamel, P. and Knafou, R.: Le tourisme dans la centralité parisienne, in: La métropole parisienne: Centralités, inégalités, proximités, edited by: Saint-Julien, T. and Le Goix, R., Belin, Paris, 37-64, 2007.

10 Équipe MIT: Tourismes 1: Lieux communs, Belin, Paris, 2002.

Équipe MIT: Tourismes 2: Moments de lieux, Belin, Paris, 2005.

Fagnoni, E. and Aymard, C.: Entre inertie et dynamique touristique: Le cas parisien, Téoros, 21, 1, 4-11, 2002.

Freyer, W.: Stadtmarketing und Tourismus, in: Städtetourismus, edited by: Landgrebe, S. and 15 Schnell, P., Oldenbourg, Munich, 29-49, 2005.

Freytag, T.: Tourism in Heidelberg: Getting a picture of the city and its visitors, in: City tourism 2002: Proceedings of European Cities Tourism's international conference in Vienna, Austria, 2002, edited by: Wöber, K. W., Springer, Vienna, 211-219, 2002.

Freytag, T.: Städtetourismus in europäischen Grossstädten: Eine Hierarchie der Standorte und aktuelle Entwicklungen der Übernachtungszahlen, DISP, 169, 2, 56-67, 2007.

Giddens, A.: The constitution of society: Outline of the theory of structuration, Polity Press, Cambridge, 1984.

Groß, S. and Schröder, A.: Handbook of low cost airlines, Schmidt, Berlin, 2007.

Hancock, C.: Paris et Londres au XIXème siècle: Représentations dans les guides et récits de voyage, Éditions CNRS, Paris, 2003.

Hennig, C.: Reiselust: Touristen, Tourismus und Urlaubskultur, Suhrkamp, Stuttgart, 1999.

Huning, S. and Novy, J.: Tourism as an engine of neighborhood regeneration? Some remarks towards a better understanding of urban tourism beyond the 'beaten path', Working Paper Series 006-2006, Center for Metropolitan Studies, Berlin, available at: http://www. metropolitanstudies.de/fileadmin/filestorage/huning-novy_006-2006.pdf, access: 7 February 2008, 2006.

Jagnow, E. and Wachowiak, H.: Städtetourismus zwischen Geschäftsreisen und Events, in: Nationalatlas Bundesrepublik Deutschland: Freizeit und Tourismus, edited by: Institut für

Tourist practices of

repeat visitors in

Paris

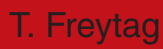

Title Page

Abstract Introduction

Conclusions References

Tables $\quad$ Figures

14

- I

4

Back

Close

Full Screen / Esc

Printer-friendly Version

Interactive Discussion

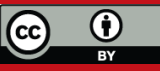


Länderkunde, Spektrum Akademischer Verlag, Heidelberg, 108-111, 2000.

Jules-Rosette, B.: Black Paris: Touristic simulations, Ann. Tourism Res., 21, 4, 679-700, 1994.

Keul, A. G. and Küheberger, A.: Die Strasse der Ameisen: Beobachtungen und Interviews zum Salzburger Städtetourismus, Reihe tourismuswissenschaftliche Manuskripte 1, Profil, 5 Vienna, 1996.

Klurman, M. (Ed.): Fodor's Paris 2004, Fodors, New York, 2004.

Knafou, R.: L'urbain et le tourisme: Une construction laborieuse, in: Mondes urbains du tourisme, edited by: Duhamel, P. and Knafou, R., Belin, Paris, 9-21, 2007.

Kozak, M.: Repeaters' behavior at two distinct destinations, Ann. Tourism Res., 28, 3, 785-808, 2001.

Lazzarotti, O.: Habiter: La condition géographique, Belin, Paris, 2006.

Lazzarotti, O.: "L'habiter touristique" et la ville, in: Mondes urbains du tourisme, edited by: Duhamel, P. and Knafou, R., Belin, Paris, 323-332, 2007.

MacCannell, D.: The tourist: A new theory of the leisure class, Macmillan, London, 1976.

Meng, L., Zipf, A., and Reichenbacher, T. (Eds): Map-based mobile services: Theories, methods and implementations, Springer, Berlin, 2004.

Molz, J. G.: Travels in blended geographies: Technologies, Mobilities and 'new' tourist destinations, 'Mobilities, technologies, and travel' workshop, Roskilde University, 20 April 2006, available at: http://www.ruc.dk/upload/application/pdf/150408fc/JGermannMolz\% 20Roskilde\%20Paper.pdf, access: 7 February 2008, 2006.

Observatoire économique du tourisme parisien: Chiffre-clés du tourisme à Paris en 2005, Office du Tourisme et des Congrès de Paris, Paris, 2006.

Observatoire économique du tourisme parisien: Le tourisme à Paris: Chiffre clés 2006, Office du Tourisme et des Congrès de Paris, Paris, available at: http://fr.parisinfo.com/uploads/bd/ /chiffres_cles_2007_2.pdf, access: 7 February 2008, 2007.

Office du Tourisme et des Congrès de Paris: Paris est à vous: 2006-2007, Casterman, Paris, 2006.

Pearce, D. G.: Tourism in Paris: Studies at the microscale, Ann. Tourism Res., 26, 1, 77-97, 1998a.

30 Pearce, D. G.: Tourist districts in Paris: Structure and functions, Tourism Manage., 19, 1, 4965, 1998b.

Pearce, P. L.: The social psychology of tourist behaviour, International series in experimental social psychology 3, Pergamon, Oxford, 1982.

\section{SGD}

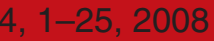

Tourist practices of

repeat visitors in

Paris

T. Freytag

Title Page

Abstract Introduction

Conclusions References

Tables $\quad$ Figures

I

4

$\checkmark$

Back

Close

Full Screen / Esc

Printer-friendly Version

Interactive Discussion

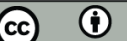


Pearce, P. L.: The Ulysses factor: Evaluating visitors in tourist settings, Springer, New York, 1988.

Pletsch, A.: Paris auf sieben Wegen: Ein geographischer Reiseführer, Studien zur internationalen Schulbuchforschung 105, Verlag Hahnsche Buchhandlung, Hannover, 2000.

5 Sacareau, I. and Stock, M.: Qu'est-ce que le tourisme?, in: Le tourisme: Acteurs, lieux et enjeux, edited by: Stock, M., Dehoorne, O., Duhamel, P., Gay, J. C., Knafou, R., Lazzarotti, O., Sacareau, I. and Violier, P., Belin, Paris, 7-32, 2003.

Sallet-Lavorel, H.: Pour un tourisme participatif en lle-de-France: Encourager le rapprochement entre visiteurs et Franciliens, IAURIF - Conseil regional d'lle-de-France, Paris, 2003.

10 Selby, M.: Understanding urban tourism: Image, culture and experience, Tauris, London, 2004.

Shaw, G., Agarwal, S., and Bull, P.: Tourism consumption and tourist behaviour: A British perspective, Tourism Geogr., 2, 3, 264-289, 2000.

Sheringham, M. (Ed.): Parisian Fields, Reaktion Books, London, 1996.

Shoval, N. and Isaacson, M.: Sequence alignment as a method for human activity analysis in space and time, Ann. Assoc. Am. Geogr., 97, 2, 282-297, 2007.

Smith, S. L. J.: The measurement of global tourism: Old debates, new consensus, and continuing challenges, in: A companion to tourism, edited by: Lew, A. A., Hall, C. M., and Williams, A. M., Blackwell, Oxford, 25-35, 2004.

Stock, M.: Habiter touristiquement la ville, in: Mondes urbains du tourisme, edited by: Duhamel, P. and Knafou, R., Belin, Paris, 25-29, 2007.

Towner, J.: An historical geography of recreation and tourism in the Western world: 1540-1940, Wiley, Chichester, 1996.

Urry, J.: The tourist gaze: Leisure and travel in contemporary societies, Sage, London, 1990.

Urry, J.: Sociology beyond societies: Mobilities for the twenty-first century, Routledge, London, 2000.

Vajda, J.: L'élite voyageuse et la transformation de l'espace urbain parisien, 1855-1937, in: Mondes urbains du tourisme, edited by: Duhamel, P. and Knafou, R., Belin, Paris, 116-127, 2007.

Wang, D.: Tourist behaviour and repeat visitation to Hong Kong, Tourism Geogr., 6, 1, 99-118, 2004.

Williams, A. M. and Hall, C. M.: Tourism and migration: New relationships between production and consumption, Tourism Geogr., 2, 1, 5-27, 2000.

Williams, A. M. and Hall, C. M.: Tourism, migration, circulation and mobility: The contingencies

Tourist practices of

repeat visitors in

Paris

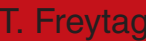

Title Page

Abstract Introduction

Conclusions References

Tables $\quad$ Figures

14

$>1$

4

$\triangleright$

Back

Close

Full Screen / Esc

Printer-friendly Version

Interactive Discussion

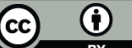


of time and place, in: Tourism and migration: New relationships between consumption and production, edited by: Hall, C. M. and Williams, A. M., Kluwer, Dordrecht, 1-52, 2002.

SGD

$4,1-25,2008$

\section{Tourist practices of}

repeat visitors in

Paris

T. Freytag

Title Page

\section{Abstract}

Introduction

Conclusions

References

Tables

Figures

1

4

Back Close

Full Screen / Esc

Printer-friendly Version

Interactive Discussion

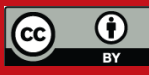




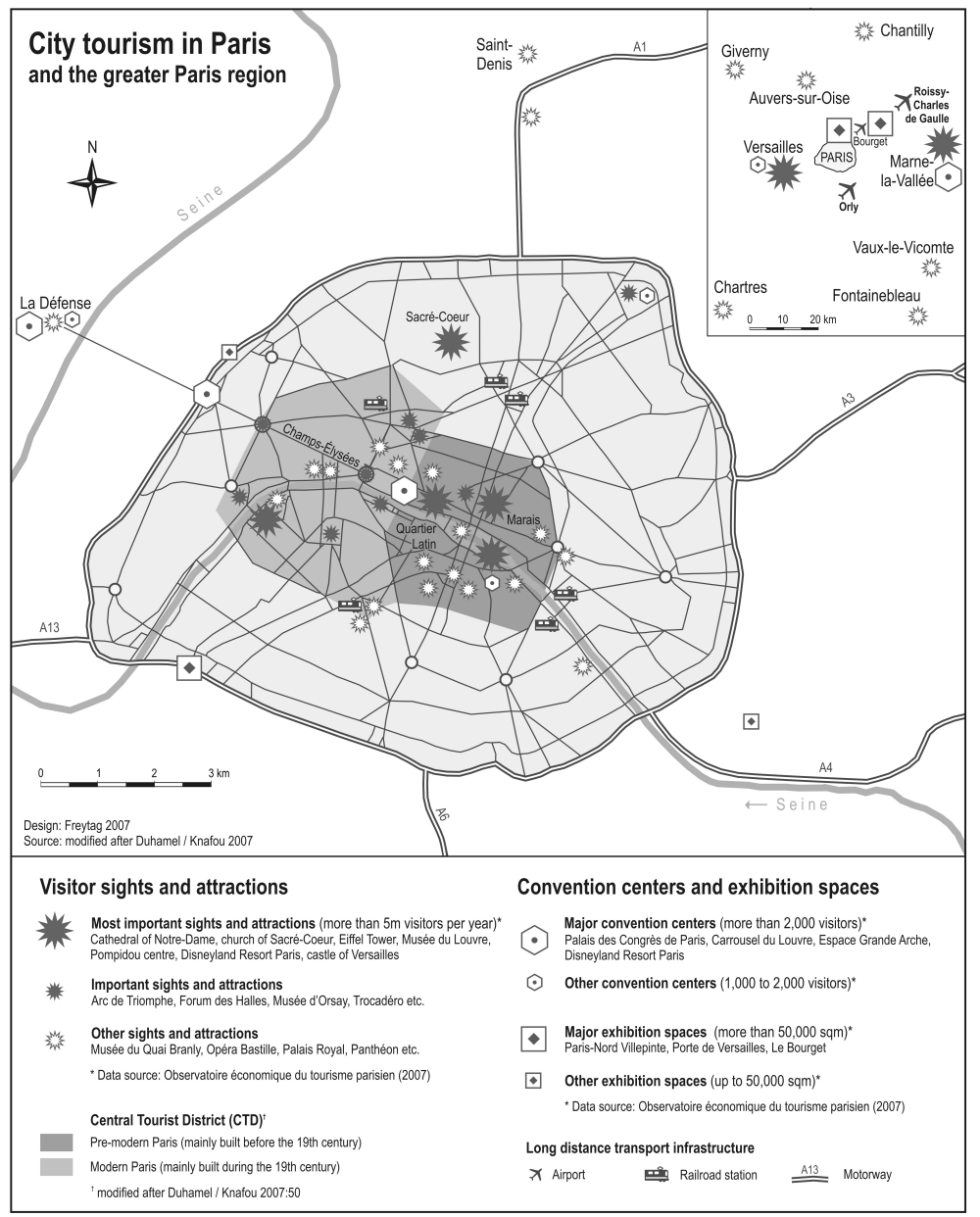

SGD

$4,1-25,2008$

Tourist practices of repeat visitors in Paris

T. Freytag

Title Page

Abstract Introduction

Conclusions References

Tables

Figures

14

- I

4

Back

Close

Full Screen / Esc

Printer-friendly Version

Interactive Discussion

Fig. 1. Major sights and locations for leisure and business tourism in Paris. 
Table 1. Visitors' priorities in sight-seeing and other activities during their stay in Paris (in \%; own survey, November 2006, $n=201$ ).

\begin{tabular}{|c|c|c|c|c|}
\hline Item & Total $n=197$ & First time visitors & 2nd or 3rd time visitors & Repeat visitors (4th visit or more) \\
\hline Number of respondents & 197 & 82 & 52 & 63 \\
\hline \multicolumn{5}{|l|}{ Sights to be visited this time } \\
\hline Montmartre area & 74.1 & 74.4 & 78.8 & 69.8 \\
\hline Louvre (enter museum) & 57.4 & 82.9 & 48.1 & 31.7 \\
\hline Notre-Dame (enter cathedral) & 55.3 & 62.2 & 69.2 & 34.9 \\
\hline Eiffel Tower (go up) & 53.8 & 72.0 & 53.8 & 30.2 \\
\hline Champs-Élysées & 66.0 & 67.1 & 76.9 & 55.6 \\
\hline Arc de Triomphe (take a look at) & 64.5 & 72.0 & 67.3 & 52.4 \\
\hline Grand boulevards & 40.6 & 46.3 & 34.6 & 38.1 \\
\hline Small boutiques & 40.1 & 40.2 & 36.5 & 42.9 \\
\hline Department stores & 37.1 & 41.5 & 34.6 & 33.3 \\
\hline Château de Versailles & 37.1 & 46.3 & 38.5 & 23.8 \\
\hline Quartier Latin & 35.5 & 39.0 & 34.6 & 31.7 \\
\hline Pompidou centre & 34.0 & 36.6 & 26.9 & 25.4 \\
\hline Marais & 26.9 & 23.2 & 21.2 & 36.5 \\
\hline Musée d'Orsay & 24.4 & 20.7 & 23.1 & 30.2 \\
\hline La Défense & 23.4 & 24.4 & 30.8 & 15.9 \\
\hline \multicolumn{5}{|l|}{ Very important activities } \\
\hline Taking pictures & 63.5 & 68.3 & 80.8 & 42.9 \\
\hline Spending time with travel partners & 56.3 & 54.9 & 57.7 & 57.1 \\
\hline Escaping from daily life & 55.8 & 51.2 & 59.6 & 58.7 \\
\hline Wine and dine & 47.7 & 47.6 & 53.8 & 42.9 \\
\hline Going out in the evening & 46.7 & 46.3 & 40.4 & 52.4 \\
\hline Cultural events & 42.1 & 43.9 & 30.8 & 49.2 \\
\hline Going to cafés & 36.5 & 29.3 & 46.2 & 38.1 \\
\hline Shopping & 29.9 & 24.4 & 36.5 & 31.7 \\
\hline Watching fashion & 20.3 & 18.3 & 25.0 & 19.0 \\
\hline \multicolumn{5}{|l|}{ Strongly agreed statements } \\
\hline Attractive architecture & 75.1 & 74.4 & 80.8 & 71.4 \\
\hline Nice atmosphere in Paris & 55.8 & 48.8 & 61.5 & 60.3 \\
\hline Expensive city & 54.3 & 54.9 & 57.7 & 50.8 \\
\hline Good cafés and restaurants & 49.2 & 42.7 & 57.7 & 50.8 \\
\hline Easy to find one's way & 38.1 & 34.1 & 44.2 & 38.1 \\
\hline Excellent shopping facilities & 36.0 & 34.1 & 34.6 & 39.7 \\
\hline Sometimes too many tourists & 28.9 & 32.9 & 28.8 & 23.8 \\
\hline
\end{tabular}

$4,1-25,2008$

\section{Tourist practices of repeat visitors in Paris \\ T. Freytag \\ Title Page}

Abstract Introduction

Conclusions References

Tables

Figures

1

$>1$

4

Back

Close

Full Screen / Esc

Printer-friendly Version

Interactive Discussion 